\title{
Changing Landscapes
}

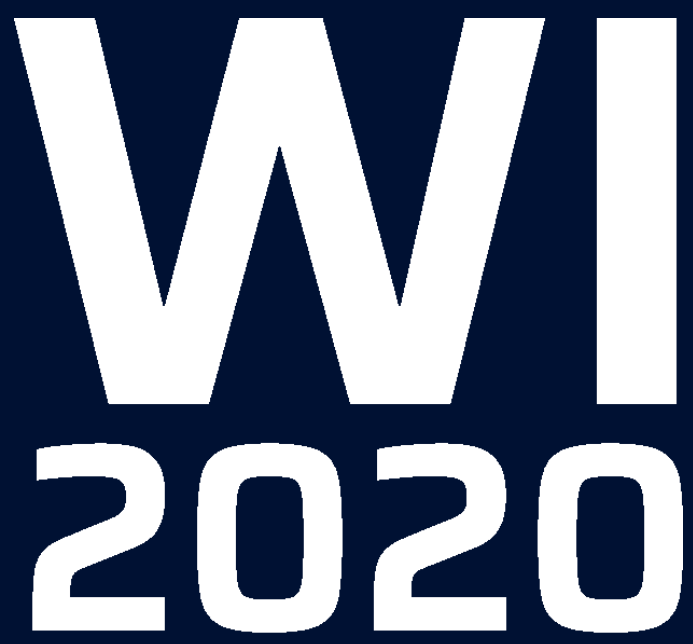

\section{Entwicklungen, Chancen und Herausforderungen der Digitalisierung}

Proceedings der 15. Internationalen Tagung Wirtschaftsinformatik 2020

Gronau, N., Heine, M., Krasnova, H., Pousttchi, K. (Hrsg.) 


\title{
Enriching E-Participation through Augmented Reality: First Results of a Qualitative Study
}

\author{
Jonas Fegert $^{1,2}$, Jella Pfeiffer ${ }^{3}$, Christian Peukert $^{2}$, and Christof Weinhardt ${ }^{2,1}$ \\ ${ }^{1}$ FZI Research Center for Information Technology, Information Management and Analytics, \\ Karlsruhe, Germany; ${ }^{2}$ KIT Karlsruhe Institute of Technology, Institute of Information Systems \\ and Marketing, Karlsruhe, Germany; ${ }^{3}$ Justus Liebig University Giessen, Chair of Digitaliza- \\ tion, E-Business and Operations Management, Giessen, Germany \\ fegertefzi.de, jella.pfeiffer@wirtschaft.uni-giessen.de \\ \{christian.peukert, christof.weinhardt\}@kit.edu
}

\begin{abstract}
Recent disputes over public construction projects show that the public is interested in urban development. When construction projects lack communication about its impact, agenda and costs, citizens might feel overheard and protests may arise. As a consequence, trust in public administration and politics could suffer serious damage. Following the idea of digital government, it is crucial not only to replicate and digitize established participation procedures, but rather to include new possibilities that e-participation offers. In this article, we present preliminary results of a qualitative study on using augmented reality for e-participation. Based on the study's results, we derive metarequirements for an e-participation application employing this technology. Interestingly, our empirical findings suggest that users only seek information via the application up to a certain level of participation.
\end{abstract}

Keywords: Digital Government, E-Participation, Qualitative Research, Augmented Reality

\section{Introduction}

Public debates over significant public construction projects in Germany such as the Stuttgart train station, the Hamburg concert hall and the Berlin Monument to Freedom and Unity show that citizens are interested in construction projects within their urban environment and develop their own opinions about them. These examples show that when construction projects lack communication and, in turn, citizens feel overheard, disputes and protests can arise which might affect the overall trust in public administration and politics $[1,2]$. One solution to this problem might be to involve citizens better in the initial project development. Following the idea of digital government [3], governing processes should be transformed to the digital age not only by replicating and digitizing established procedures, but rather through employing new digital opportunities. Some research has already shown the innovative opportunities that digital technologies can provide for e-participation [4], such as using wearables [5] and public displays [6] for e-participation. In this short paper, we focus on Augmented Reality

$15^{\text {th }}$ International Conference on Wirtschaftsinformatik,

March 08-11, 2020, Potsdam, Germany 
(AR) technology, that has become increasingly accepted in consumer markets [7]. Although several studies on the use of AR in the field of consumer decision-making exist [e.g., 6-8], there does not seem to be sufficient research on the implementation of $\mathrm{AR}$ in the public sector. We will show preliminary results from an ongoing study about the implementation of AR in civic participation processes for public construction projects. Therefore, the paper is guided by the following research question (RQ): Whether and to what extent does the use of AR technology in the planning and design of construction projects increase the citizen's participation in and acceptance of public projects?

To answer this question, we conducted interviews with stakeholders involved in an AR-e-participation project in the city of Karlsruhe. In the city's zoological garden, they are planning to build a new enclosure for ring-tailed lemurs, which should be built on an already existing island in one of the zoo's lakes. The lemurs will move freely on the island and the island itself will become accessible for the visitors via bridges. The island-enclosure is an architectural novelty for the zoo, which is why they would like to involve the visitors in its construction process. Although Karlsruhe operates the zoo, the construction will be financed through private donations. The eparticipation project aims at programming an AR application (app) that enables citizens to participate in the development of the enclosure on the island and get a feeling for its accessibility. The app allows participants to see different versions of the enclosure as well as submit their feedback, comments and design suggestions. The app runs on smartphones or tablets and is controlled by lifting, lowering and turning the device. We chose this use case because both, the zoo and the city, are interested in testing new ways of participation in this construction project, while certain details of the enclosure are still up for discussion and modification. Public construction projects typically involve numerous stakeholders. It also applies for this use case, which is why it offers a high degree of generalizability. Following the Design Science Research Methodology (DSRM) [11], we start with the initial activity "problem identification and motivation" and thereby derive meta-requirements for the AR eparticipation app. With these meta-requirements we contribute to research on the design of AR-based apps that enable e-participation.

\section{Theoretical Foundation: E-Participation and AR}

As a subdivision of digital government, e-participation research focuses on the role of citizen engagement with the government. As defined by Macintosh [12], eparticipation gives citizens an opportunity to participate in and influence policy decisions using information and communication technologies (ICT). Sanford and Rose [13] use Habermas' arguments on the importance of "effective communication and informed decision making" [13 p. 406] for democracies in their literature review about e-participation. The spectrum of public participation suggests five steps of participation: informing, consulting, involving, collaborating and empowering the public [14-16]. In our study, we use these steps to deduce our meta-requirements.

The theoretical origin of AR goes back to the 1960s [17], while its practical application followed 30 years later [18] and only entered the mass market in recent years. 
We follow Azumas [18] definition, who defines AR as a real-time 3D visualization that combines real surroundings with virtual elements. Information like text objects or images can be displayed via different types of hardware [19]. Using AR for the visualization of construction projects in e-participation contexts is an almost self-evident idea, since architects are already producing CAD models, which can be easily adapted. Those visualizations might give a better understanding of the construction at the site. Existing research emphasizes the potential of AR for participation processes, e.g. in landscape architecture [20] or for its application in urban planning [21], but does not include forms of e-participation. The scientific relevance of this study thus flows from the lack of comparable IS research. There is no research on the possible benefits of the use and design of an AR e-participation app.

\section{Research Design and Data Collection}

Our research follows a Design Science [11] approach. Within this approach, we use a mixed method design consisting of a qualitative research (QR) study focusing on problem and motivation identification (first activity) and a quantitative study that evaluates the prototype of the e-participation artifact (fifth activity) [11]. Within this short paper, we only report first results of the QR study, which was conducted following Kaiser's [22] approach. The data collection took place in June 2019. For the interviews, which we recorded, our guideline was transparent in its structure to the interviewees. To assure a minimum level of common knowledge, the interviews began with an introduction into the technology, in which we informed the participants about $\mathrm{AR}$ and gave them the possibility to test it with a simple prototype: To illustrate AR, we presented the interviewees with a postcard with markers that activated an ARvisualization of a construction project. Further, a head-mounted display was used to demonstrate VR to the interviewees by showing them a panorama view of the construction project. Thereby, the interviewees could familiarize themselves with the technologies and the ways the latter can be used for the visualization of construction projects. We asked the interviewees about the relevance [23], acceptance [23, 24], incentive concepts [23] and their possible degree of participation $[14,15]$ in an ARbased e-participation app. We executed 20 face-to-face semi-structured interviews with 27 participants (some were conducted with groups of up to three people) representing the different stakeholders (zoo management and employees (37\%), visitors $(26 \%)$, friends of the zoo association $(11 \%)$, city council members $(15 \%)$, city employees $(4 \%)$ and software engineers $(7 \%))$. The median age of the interviewees was 45 years (min. 18, max. 80) and among the interviewees were $51.85 \%$ female.

\section{$4 \quad$ First Results and Meta-Requirements}

The interviewees showed high interest in AR despite having had only little previous knowledge about the technology. We also observed interest in using AR for eparticipation and exploring new ways of visualizing construction projects. Participants tend to associate AR with fun and games (some specifically with PokemonGo). 
Different interviewees expressed their wish for the app to be open-source and as barrier-free as possible. The interview guideline used the mentioned spectrum of participation [14] to find out about the degree of participation and the willingness to use an app to participate in a construction project. We sub classified the answers in four response options (yes, no, maybe, no response). If it comes to voting (24\% maybe, $4 \%$ no), participatory budgeting (11\% maybe, $27 \%$ no) and submitting design suggestions (19\% maybe, $33 \%$ no) some interviewees are questioning their own competence to participate. Furthermore, the interviewees showed skepticism towards onlinediscussions, and preferred non-virtual public debates instead. The participation levels of receiving information ( $89 \%$ yes), giving feedback (85\% yes) and donating for a project ( $78 \%$ yes) were assessed positively. Our empirical results therefore suggest that users only seek information and participation through the app up to a certain level. Based on the study's results, we derive meta-requirements for an e-participation app, which employs AR:

Table 1. Meta-Requirements (MR) for an e-participation application using AR

\begin{tabular}{ll}
\hline \multicolumn{1}{c}{$M R$} & \\
\hline $\begin{array}{l}\text { Motiva- } \\
\text { tion }\end{array}$ & $\begin{array}{l}M R-1.1 \text { Possibility to access the app easily and to navigate efficiently to the } \\
\text { desired objective } \\
M R-1.2 \text { Possibility to access the app as barrier-free as possible (e.g. via differ- } \\
\text { ent end devices) and to guarantee that individuals with lower experience } \\
\text { levels (e.g. higher age) do not feel excluded } \\
\end{array}$ \\
& $M R-1.3$ Possibility to stay involved in the project through gamification \\
\hline Infor- & $M R-2.1$ Possibility to show visualizations with AR \\
mation & $M R-2.2$ Possibility to put the participation items in a broader context of con- \\
& tent \\
\hline Empow- & $M R-3.1$ Possibility to empower the users to feel able to participate esp. when \\
erment & it comes to voting, participatory budgeting and submitting design suggestions \\
\hline Trans- & $M R-4.1$ Possibility to learn about the initial motivation of the participation \\
parency & process \\
& $M R-4.2$ Possibility to stay informed and involved after the initial participation \\
& process \\
& $M R-4.3$ Possibility to have a fully transparent donation process \\
& $M R-4.4$ Possibility to learn about the data usage
\end{tabular}

\section{Outlook}

In this paper, we presented first results of our study, which helped us to identify problems and understand motivations in our DSRM-cycle. We will continue with defining objectives (activity two) and designing and developing the artifact (activity three) [11]. Moreover, we established meta-requirements for the development of an eparticipation app using AR, especially for construction projects in the public sector. In further research, we will continue the structured content analysis of the collected data by transcribing and coding the interviews entirely and will expand the analysis so as 
to include data about the usefulness of VR for e-participation. We thereby hope to find out more about the expectations, possible challenges and the potential of these technologies for e-participation. 


\section{References}

1. Brettschneider, F.: Großprojekte zwischen Protest und Akzeptanz: Legitimation durch Kommunikation. In: Brettschneider, F., Schuster, W. (eds.) Stuttgart 21: Ein Großprojekt zwischen Protest und Akzeptanz. pp. 319-328. Springer Fachmedien Wiesbaden, Wiesbaden (2013)

2. Thaa, W.: „Stuttgart 21 “ - Krise oder Repolitisierung der repräsentativen Demokratie? Politische Vierteljahresschrift. 54, 1-20. Springer VS, Wiesbaden (2013)

3. Falk, S., Römmele, A., Silverman, M.: The Promise of Digital Government. In: Falk, S., Römmele, A., and Silverman, M. (eds.) Digital Government: Leveraging Innovation to Improve Public Sector Performance and Outcomes for Citizens. pp. 3-23. Springer International Publishing, Cham (2017)

4. Thiel, S.-K., Fröhlich, P., Sackl, A.: Nutzerorientierte Gestaltung von interaktiver EPartizipation. In: Leitner, M. (ed.) Digitale Bürgerbeteiligung: Forschung und Praxis Chancen und Herausforderungen der elektronischen Partizipation. pp. 127-161. Springer Fachmedien Wiesbaden, Wiesbaden (2018)

5. Wilson, A., Tewdwr-Jones, M., Comber, R.: Urban planning, public participation and digital technology: App development as a method of generating citizen involvement in local planning processes. Environment and Planning B: Urban Analytics and City Science. 46, 286-302. SAGE Publishing, Thousand Oaks (2019)

6. Du, G., Degbelo, A., Kray, C.: Public Displays for Public Participation in Urban Settings: A Survey. In: Proceedings of the 6th ACM International Symposium on Pervasive Displays. pp. 17:1-17:9. ACM, New York (2017)

7. Rese, A., Baier, D., Geyer-Schulz, A., Schreiber, S.: How augmented reality apps are accepted by consumers: A comparative analysis using scales and opinions. Technological Forecasting and Social Change. 124, 306-319. Elsevier, Amsterdam (2017)

8. Javornik, A.: Augmented reality: Research agenda for studying the impact of its media characteristics on consumer behaviour. Journal of Retailing and Consumer Services. 30, 252-261. Elsevier, Amsterdam (2016)

9. Scholz, J., Smith, A.N.: Augmented reality: Designing immersive experiences that maximize consumer engagement. Business Horizons. 59, 149-161. Elsevier, Amsterdam (2016)

10. 10. Pantano, E., Rese, A., Baier, D.: Enhancing the online decision-making process by using augmented reality: A two country comparison of youth markets. Journal of Retailing and Consumer Services. 38, 81-95. Elsevier, Amsterdam (2017)

11. Peffers, K., Tuunanen, T., Rothenberger, M.A., Chatterjee, S.: A Design Science Research Methodology for Information Systems Research. Journal of Management Information Systems. 24, 45-77. Taylor \& Francis Online, Milton Park (2007)

12. Macintosh, A.: Characterizing E-Participation in Policy-Making. In: Proceedings of the Proceedings of the 37th Annual Hawaii International Conference on System Sciences (HICSS'04) - Track 5 - Volume 5. pp. 50117.1. IEEE Computer Society, Washington DC (2004)

13. Sanford, C., Rose, J.: Characterizing eParticipation. International Journal of Information Management. 27, 406-421. Elsevier, Amsterdam (2007)

14. International Association for Public Participation: IAP2 Spectrum of Public Participation, https://cdn.ymaws.com/www.iap2.org/resource/resmgr/pillars/Spectrum_8.5x11_Print.pdf (Accesed: 20.07.2019)

15. Nelimarkka, M., Nonnecke, B., Krishnan, S., Aitumurto, T., Catterson, D., Crittenden, C., Garland, C., Gregory, C., Huang, C.-C. (Allen), Newsom, G., Patel, J., Scott, J., Goldberg, 
K.: Comparing Three Online Civic Engagement Platforms using the Spectrum of Public Participation. Berkeley (2014)

16. Nabatchi, T.: Putting the "Public" Back in Public Values Research: Designing Participation to Identify and Respond to Values. Public Administration Review. 72, 699-708. Wiley-Blackwell, Hoboken (2012)

17. Sutherland, I.E.: The Ultimate Display. In: Proceedings of the IFIP Congress. 506-508. Cambridge (1965)

18. Azuma, R.T.: A survey of augmented reality. Presence: Teleoperators \& Virtual Environments. 6, 355-385. MIT Press, Cambridge (1997)

19. Kind, S., Ferdinand, J.-P., Jetzke, T., Richter, S., Weide, S.: Virtual und Augmented Reality. Büro für Technikfolgen-Abschätzung beim Deutschen Bundestag, Berlin (2019)

20. Goudarznia, T., Pietsch, M., Krug, R.: Testing the Effectiveness of Augmented Reality in the Public Participation Process: A Case Study in the City of Bernburg. Journal of Digital Landscape Architecture. 2, 244-251. Wichmann Verlag, Berlin (2017)

21. Allen, M., Regenbrecht, H., Abbott, M.: Smart-phone Augmented Reality for Public Participation in Urban Planning. In: Proceedings of the 23rd Australian Computer-Human Interaction Conference. 11-20. ACM, New York (2011)

22. Kaiser, R.: Qualitative Experteninterviews: Konzeptionelle Grundlagen und praktische Durchführung. Springer Fachmedien Wiesbaden, Wiesbaden (2014)

23. Venkatesh, V., Davis, F.D.: A Theoretical Extension of the Technology Acceptance Model: Four Longitudinal Field Studies. Management Science. 46, 186-204. INFORMS, Cantonville (2000)

24. Pereira, G. V., Rinnerbauer, B., Ginner, M., Parycek, P.: Categorizing Obstacles in eGovernment: Formal and Informal. Proceedings of the 10th International Conference on Theory and Practice of Electronic Governance. 157-166. ACM, New York (2017) 